\title{
Depiction of Dystopian World in Alexander Payne's Downsizing
}

Mariamma Angel A

Student

Pondicherry University affiliated

Tagore Govt. College of Education

Andaman and Nicobar Islands, India

adzchoir796@gmail.com

\section{Abstract}

This paper attempts to study Alexander Payne's Downsizing through a dystopian perspective in which it highlights the aspects of dystopia in Downsizing. It discusses the working of a dystopian government which is oppressive and describing the instances that signifies that the government depicted in Downsizing as tyrannical. It projects the ways in which the government tries to justify their deeds of downsizing their rivalries. This chapter also analyses the effects caused by technology in facilitating the destruction of nature and mankind in a dystopian world. It also describes the aspects of eco- dystopia present in the movie in which it highlights the impact of the interference of human beings with nature which subsequently leads to the possibility of an apocalyptic vision. It discusses the relationship of dominance and subjectivity between man kind and nature where human beings generally take on the role of the master and nature is treated as an entity to be destroyed and exploited by human beings.

Keywords: Dystopia, Political Instability, Eco-Dystopia, Science And Technological Advancement. 
Introduction

Downsizing depicts the life of people who consider the life of human beings to be more precious than the nature world. In the movie, the scientists predict of an apocalypse and find a panacea for that. They discover that the major cause of the upcoming disaster is over growing population, deforestation and industrialization due to which the earth faces the problem of global warming, emission of the greenhouse gases, specifically methane from the polar region which creates imbalance in the ecological equilibrium. As a solution for this problem they invent a technology named 'Downsizing' which is meant to minimize a normal size person to mere centimeters. This technology gives a prospect of a luxurious life for all those who can afford it and also for all those who are willing to opt for it. But it's exceptional for all those who are under any medication.

Dystopia

A dystopia is an imagined society in which "the conditions of life are miserable, characterized by human misery, war, poverty, over population, oppression, violence, disease, and or pollution" ("Dystopia"). The key elements of dystopia includes the end of the world, in which usually something happens to change the world like nuclear war, global warming, an alien invasion or any other catastrophe, technological development enslaves human, the society is oppressed and the illusion of a perfect society is maintained through the technological, political, capitalist, corporate, totalitarian government control. A dystopian government uses propaganda to exert power and control over the society. Furthermore, there is restriction in the information provided to the citizens; their liberty to express their views is curbed by the government. Citizens 
in a dystopian society are under constant surveillance. Natural world is exploited and almost banished in dystopia.

Downsizing depicts the functioning of an oppressive government, which claims to take decisions for the welfare of the entire universe, but the notion behind this favorable action is to exploit and marginalize people by creating an illusionary world with the prospect of peace, equality and prosperity. The downsizing technology which was invented to downsize people to tackle population overgrowth is used by the tyrannical government to downsize their rival dictators. Such authoritative government is shown as seeking pleasure in tormenting their enemies. A dominant ideology is used to control the everyday lives of people (Drass and Kiser 423) and "If ideology is too narrow and does not allow room for alternate forms of belief, it can start to serve as a form of reality control. If the government has the ability to control people's realities, then they can control people's thoughts and actions" (Neogi). In Downsizing, the miniaturization of people is set as a dominant ideology through which the government tries to control the lives of its citizens. Corporate world plays a vital role in establishing control over the thoughts and actions of people by influencing their thoughts through media, digital marketing and advertisements.

"False consciousness," is a term used by Marxists to demonstrate how those in power can exploit the working class. In Downsizing people are kept under false consciousness wherein they accept the dominant thought that downsizing is a way to cope up with the environmental degradation caused due to over population. They are unable to understand the reality of their situation because of this ideology constructed by government. The government uses media as a means to manipulate the minds and beliefs of people and thereby controlling their thoughts and actions. For instance, Paul Safranek and his wife Audrey are enticed by the prospect of living a 
luxurious life after being downsized through media and their downsized friends. In a normal sized life, they will have to struggle hard to have the economic value that one need to have in order to live comfortably.

"In most dystopian novels, a tyrannical government is trying to suppress and control its citizens by taking away their individuality" (Kendall). The downsized people in leisure- land are kept under constant surveillance. As the process of downsizing is irreversible, once a person is downsized, he is confined to the walls of protected areas, one of which is called Leisure-land. Life without that protected mesh could be miserable as the mesh not only protects them from the harmful rays of the sun which could damage their skin but also safeguards them from the insects like mosquitoes. In this manner, these people are robbed off their individuality, succumbed to the constraints of government imposed upon them as they couldn't participate in the economy of the country as well as their life is under constant threat of being exposed to the outer atmosphere which may prove to be harmful for their existence.

\section{Political Instability}

The government creates political instability and social unrest by downsizing the immigrants coercively without their willingness. In Downsizing, Ngoc Lan is the victim of racist oppression and prejudice of an unjust government, a Vietnamese environmental and political activist, who voiced against govt. to preserve her land and is downsized as a punishment. People like her are denied off their political rights and live at the outskirts of the protected area depicting the prevalent class hierarchy. The oppressive system subjugates the under-privileged minority into alienation as the elites in the movie suppresses the minority like Ngoc Lan to work for their welfare (Hardy). Ngoc Lan represents all those "who are empowered, fearless, strong, and determined to find a way to survive and face their fears. Major characters have influential 
personalities that oppressive governments attempt to control, but cannot" (Kendall). Even though she is downsized and her cultural heritage and ethnic identity is shattered by the government, she serves as a humanitarian for the welfare of her community.

Eco-dystopia

The theme of "eco-dystopian stories depict post-apocalyptic societies in which some sort of ecological catastrophe has occurred, including scarce natural resources and a damaged agricultural system" (Ertelt) is one of the thematic concern in dystopia. In Downsizing, the scientists predict the vision of apocalypse due to the emission of methane gas, population overgrowth and climate change, which led to the ecological imbalance and global catastrophe. It highlights the impact of human activity on nature. The society in dystopia isolates the characters from the natural world. It is explicitly seen in the movie that the people lacks concern for their environment. Even Scientists like Dr. Asbjornsen by claiming that homo-sapiens are the most precious creatures to be extinct, gradually disregards the vitality of nature in their life. Most of the people projected in the movie are seen obsessed with the pursuit of hedonistic and materialistic pleasure which simultaneously leaves no space for ecological consciousness among them.

Science and Technological Advancement

Science and technological advancement is meant to facilitate the lives of human beings and to provide safety to our society. According to M. Keith Booker the technological progresses of the period are responsible for the dynamic change in utopian thought and the advent of dystopian vision. He claims that "the technological achievements predicted by early scientists like Bacon were being realized ... [and] offered hints that science would not have an entirely emancipatory effect on humanity (6). According to his views, scientific developments and 
inventions may cause the suppression and control of the human beings. The science and technological innovation projected in Downsizing not only produce fatal damage to human lives but also deprives them off humanity. There is no doubt that it is for the betterment of the universe but the power that the downsized people gets access to, corrupts them. For instance, Dusan in Downsizing could be seen as the avaricious person who became downsized to become wealthy instantly. He is a black marketer and he smuggles luxury items like wine and cigar. In Downsizing, Glady's life is not taken into consideration because she has lost all her money in her treatment. Her husband died during the process of downsizing because the doctor assisting him didn't remove his golden tooth, subsequently his head exploded and he lost his life. Rather than eliminating power structure, social injustice and class hierarchy, the downsizing technology has led to the formation of community in which all these inequality persists.

In Downsizing, due to technological development, people have lost connectivity with the natural world and the next generation would probably never experience the natural world. People become redundant in the technological world as the technology takes on the role of a man by doing all the works that were once done by human hands (Murphy 475). It costs the livelihood of many people by robbing them off their employment; the worst impact is on the proletariat and laborers who make their survival in daily basis and wages. Even the private property of an individual and their independence is abolished and people live in an artificial setting in dystopian world.

The commonly occurring theme in dystopia is economy under the control of the state government. Government plays a crucial role in handling the economic affairs by determining the wages of the employees, raising the cost of living by increasing the tax amounts, etc. Such economic coercion generally is predicated on the loss of individualism and the amount of social 
control exerted by the government through the access to goods and services. In Downsizing, there is a huge impact on the world economy causing hatred and frustration among people. The amount of money spent by the consumers is reduced drastically with the gradation in the number of people becoming downsized. This has caused a huge amount of loss to the working sectors. This has created distress among the normal sized people as they have lost their jobs. Downsizing turned out to be a curse for those people who can't become downsize due to fragile health condition, financial and other personal problem.

\section{Conclusion}

At this stage of predictability of apocalypse, all that has been done so far to the earth can't be reversed, and it will take millions of years to restore the ecological balance that has been already disturbed due to various reasons. Thus, sustainable development with a nature centered approach may help to preserve the nature for the future generations and also could assure a life without causing much harm to nature. It is the prime duty as the custodians of the earth of us all, as a human being to safeguard the earth from the harmful activities that causes hazard to the ecosystem. 
Works Cited

Downsizing. Directed by Alexander Payne, Performances by Matt Damon, ChristophWalz, Hong Chau, 22 Dec. 2017, Amazon Prime, www.primevideo.com/detail/0IE6VVBHB8NOEZBO9RYWYV1VF2/ref=sr_def_c_un kc_1_1_1?sr=1-1\&qid=1553542023.

Drass, Kriss A, and Edgar Kiser. "Structural Roots of Visions of the Future: World-System Crisis and Stability and the Production of Utopian Literature in the United States, 18831975.” International Studies Quarterly, vol. 32, no. 4, 1988, pp. 421-438. JSTOR, www.jstor.org/stable/2600591. Accessed 12 Mar 2019.

“Dystopia.” New World Encyclopedia, 4 Oct. 2017, New World Encyclopedia. Www.newworldencyclopedia.org/entry/Dystopia. Accessed 12 Mar 2019.

Ertelt, Sarah. "Eco-dystopias: What Fiction Can Teach Us About Climate Change.” The Printable Post. Mar 19 2018, www.prindlepost.org/2018/03/eco-dystopias-what-fictioncan-teach-us-about-climate-change/. Accessed 12 Mar. 2019.

Hardy, Bruce. "How Alexander Payne Thought Big for Downsizing.” Vanity Fair, 6 Dec. 2017. Www.vanityfair.com/hollywood/2017/12/downsizing-alexander-payne-matt-damon.

Kendall, Jennifer. "The Appeal of Dystopian Novels for Teens." ThoughtCo, Jun. 27, 2018, thoughtco.com/dystopian-novels-and-teens-626666. Accessed 12 Mar. 2019.

Murphy, Graham L. "Dystopia." The Routledge Companion to Literature and Science, edited by Mark Bould, et al., Routledge, 2009, pp. 473-77.Bookfi, en.bookfi.net/book/1255033. 
Neogi, Nupur. "Government Representation in Dystopian Literature." Literature and digital diversity, 22 Nov. 2017, litdigitaldiversity.northeastern.edu/government-representation-in dystopian-literature/. Accessed 8 Mar. 2019. 